Tine Germ

\title{
Slika kot nadomestek za pisano besedo? Pojmovanje likovne umetnosti $v$ delih zgodnjekrščanskih piscev
}

\begin{abstract}
Ključne besede: sporočilnost likovne umetnosti, zgodnjekrščanski pisci o likovni umetnosti, svete podobe, zgodnjekrščanska ikonografija
\end{abstract}

Razmerje med podobo in pisano besedo, ki zaznamuje večji del zgodnjekrščanskih in srednjeveških polemik o vlogi umetnosti, je trdno zakoličeno z znamenito in ničkolikokrat citirano mislijo Gregorja Velikega (540-604), da so slike za nepismene to, kar je pisana beseda za ljudi, ki znajo brati: „Slike so v cerkvah zato, da lahko tisti, ki ne znajo brati, s pogledom na stene tam preberejo, česar ne morejo prebrati v knjigah «(Gregor Veliki, Pismo Serenu, PL 77, 1128). ${ }^{1}$ S tem Gregor Veliki postavi jasno razmerje med verbalnim in vizualnim zapisom, $v$ katerem je mogoče razbrati vsaj dva pomembna poudarka. Prvič: pisana beseda in likovna govorica sta $\mathrm{v}$ določenem kontekstu medsebojno zamenljivi, s čimer se avtor naveže na uveljavljeno antično tradicijo alegoričnega slikarstva in izražanja v simbolnih podobah, ki jo je krščanska umetnost sprejela brez večjih zadržkov. Drugič: v vrednotenju načinov izražanja je vzpostavljeno povsem nedvoumno hierarhično razmerje, v katerem je jezik podob degradiran na raven izraznega sredstva, ki je namenjeno nepismenim, torej manj izobraženim krogom, pretežno laični javnosti in preprostemu ljudstvu. ${ }^{2}$

Gregor Veliki likovne umetnosti nikakor ne zavrača, vendar vidi njeno vrednost predvsem v poučnosti, v zmožnosti, da približa krščanski nauk tudi najširšim slojem takrat pretežno nepismenega prebivalstva. Umetnost kristjana uči in vzgaja, zato je koristna in potrebna. Lahko bi rekli, da je Gregor Veliki s tem umetnost postavil v vlogo služabnice veri, podobno kot so v srednjem veku imeli filozofijo za »deklo teologije«. A takšna interpretacija je vse preveč poenostavljena, saj ne upošteva zgodovinskega konteksta, v katerem je bila zapisana slovita izjava. Ne smemo namreč pozabiti, da Gregor Veliki zaključuje dolgo vrsto polemik o vlogi likovne umetnosti v krščanstvu, ki so izšle izpod peres cerkvenih očetov od 2. do 5. stoletja; v njih je odnos do podob praviloma zadržan ali odkrito odklonilen.

1 Prevedeno po: W. Tatarkiewicz, History of Aestethics, II, Medieval Aesthetics, Haag/Varšava, $1970,104$.

2 Za Gregorja Velikega in njegov vpliv na odnos do likovne umetnosti gl. Celia M. Chazelle, Pictures, Books and Illiterate: Pope Gregory I's Letters to Serenus of Marseilles, Word \& Image 6 (1990), 138-153. 
Z vidika zgodnjekrščanske polemike o primernosti svetih podob in upravičenosti likovne umetnosti je takšno stališče odločna pritrditev umetnosti in priznanje njene legitimnosti s strani najvišje cerkvene avtoritete. ${ }^{3}$ Znano je, da zgodnjekrščanski pisci likovni umetnosti niso bili naklonjeni. V prvi vrsti gre seveda za vprašanje svetih podob, vendar je v tem razviden tudi odnos do celotne likovne ustvarjalnosti in njene vloge v družbi. ${ }^{4}$ Najostreje je proti podobam nastopil Tertulijan (ok. 160-220), ki je v zgodnjem 3. stoletju po Kristusu napisal spis O malikovanju, v katerem pravi, da je sam hudič poslal na svet kiparje, slikarje in izdelovalce raznih vrst podob. Trdi, da je prav umetnost izdelovanja podob postala vir malikovanja, in po njegovem prepričanju so umetniki krivi, da se je tako razširila (Tertulijan, O malikovanju, III, PL 1, 664D-665A). Poglavitni razlog, zakaj Tertulijan zavrača umetnost, je očiten: umetniki ustvarjajo podobe bogov in s tem spodbujajo malikovanje, proti kateremu se je cerkveni oče zagrizeno boril.

Tertulijan izdelovanje podob povezuje s poganstvom, kar je razumljivo, saj je živel $\mathrm{v}$ času, ko sta antična kultura in likovna umetnost doživljali svoj pozni razcvet, medtem ko je bila krščanska umetnost še v povojih. Prav posebej je bodlo v oči čaščenje podob, ki je v poznoantičnem Rimu pod vplivom vzhodnjaških kultov doseglo vrhunec. Tertulijan, ki ostro obsoja sleherno malikovanje, se nad slikarji in kiparji zgraža tudi iz drugačnih razlogov. Njihovo ustvarjanje razume kot napuh in žalitev Boga, ker naj bi umetniki poskušali s svojim delom brezsramno tekmovati z njim, ki je božanski stvarnik vsega obstoječega. ${ }^{5} \mathrm{~V}$ zavračanju likovne umetnosti in zlasti svetih podob se Tertulijan opira na tradicijo krščanskih apologetov, ki so v 2. stoletju po Kristusu afirmacijo nove vere gradili (tudi) na zavestnem razlikovanju od uveljavljene poganske prakse čaščenja podob. ${ }^{6}$

Čeprav je odnos poganske antike do vprašanja čaščenja podob zelo kompleksen, lahko z nekaj poenostavljanja vendarle rečemo, da je $\mathrm{v}$ večini kultov in religijskih praks prevladovalo prepričanje, da je $\mathrm{v}$ upodobitvi boga - bodisi v sliki, kipu ali

3 Ob tem je treba poudariti, da je papež Gregor Veliki s svojo razlago v resnici zgolj »uradno potrdil« obstoječe stanje, saj se je zgodnjekrščanska umetnost razcvetela kljub pomislekom cerkvenih piscev. Vendar njegove odločitve ne kaže podcenjevati, zlasti v luči ikonoklazma, ki se je nedolgo zatem razdivjal v Bizancu. Z avtoriteto papeža (pozneje tudi cerkvenega očeta in svetnika) je Gregor Veliki vsaj na Zahodu preprečil resnejše ikonoklastične izbruhe.

4 Za vprašanje odnosa do svetih podob v pozni antiki in zgodnjem krščanstvu gl. mdr. M. Barasch, Icon. Studies in the History of an Idea, New York/London, 1995. Med starejšimi deli je še zmeraj relevantno H. Koch, Die altchristliche Bildfrage nach den literarischen Quellen, Göttingen, 1917.

5 Tertulijan v negativnem vrednotenju likovne umetnosti in umetnikov v zgodnjem krščanstvu nikakor ni izjema. Slikarje so posamezni pisci dajali v isti koš z lahkoživci, lastniki bordelov, pijanci in pouličnimi igralci. Prim. E. Bevan, Holy Images: An Inquiry into Idolatry and Image-Worship in Ancient Paganism and in Christianity, London, 1940.

6 Gl. R. Lane Fox, Pagans and Christians: In the Mediterranean World from the Second Century AD to the Conversion of Constantine, London, 2006; Ph. F. Esler, The Early Christian World, London, 2004; R. Valantasis (ur.), Religions of Late Antiquity in Practice, Princeton, 2000. 
kakršni koli drugi likovni izvedbi - vsebovan vsaj del samega božjega bistva. Zato so prinašanje darov, molitve in različne oblike čaščenja podob ustrezen in vsesplošno priznan način izkazovanja spoštovanja in naslavljanja priprošenj bogovom. V poplavi religij in kultov, ki so v prvem stoletju krščanstva cveteli v rimskem cesarstvu, je mlada krščanska cerkev svojo identiteto oblikovala $\mathrm{z}$ radikalno drugačno liturgijsko prakso in odnosom do svetih podob. Spoštovanje zapovedi, s katero je Bog Mojzesu prepovedal izdelovanje božjih podob ( $2 \mathrm{Mz} 20,4)$, je bilo nedvomno pomemben dejavnik, saj iz prvih dveh stoletij po Kristusu skorajda nimamo ohranjenih spomenikov krščanske umetnosti. Vendar moramo ob tem upoštevati tudi različne kulturnozgodovinske dejavnike, predvsem dejstvo, da je bilo krščanstvo preganjano, da so bili pogoji za razvoj avtonomne umetnosti neugodni, da so bili tako umetniški kot finančni viri omejeni ipd.

Spisi krščanskih apologetov, kot so Aristid Atenski, Atenagora iz Aten, Justin iz Sihema in njegov učenec Tacijan, $\mathrm{z}$ doslednim nasprotovanjem malikovanju in izdelovanju podob nazorno ilustrirajo prevladujoče stališče zgodnjekrščanske cerkvene elite. ${ }^{7}$ Apologeti se v svojem grajanju podob velikokrat sklicujejo na že obstoječo antično tradicijo, kjer sta bila zavračanje in omalovaževanje čaščenja svetih podob vsaj v krogih izobražencev dodobra uveljavljena. Ironična misel grškega filozofa Ksenofana Kolofonskega (ok. 565-473 pr. n. š.), ki pravi, da bi govedo, ko bi imelo roke in bi lahko ustvarjalo podobe, svoje bogove izdelalo v podobi volov, je bila malone prislovična in cerkveni pisci so jo $\mathrm{z}$ veseljem uporabljali kot orožje v boju proti čaščenju podob. ${ }^{8}$ Ksenofanov nekoliko mlajši sodobnik Heraklit Efeški (ok. 535-475 pr. n. š.) je ljudi, ki nagovarjajo kipe bogov, primerjal z verniki, ki govorijo zidovom: »... in tu se ti molijo božjim podobam, prav ko da bi se človek s stenami pogovarjal, ker pač pojma nimajo o bitnosti bogov in herojev « (Heraklit, Fragmenti, 5). ${ }^{9}$ Svoj najpopularnejši izraz je misel o grotesknosti čaščenja božjih podob doživela $\mathrm{v}$ poznoantični parodiji Iliade, $\mathrm{v}$ pesnitvi Boj žab in miši (Batrachomyomachia), kjer se Atena Zevsu pritoži, da so ji miši obžrle plašč in da si ne more privoščiti novega, ker nima denarja za krojača. ${ }^{10}$ Krhkost, minljivost in »nemoč« materiala, iz katerega so izdelane podobe bogov, kot dokaz, da v podobah ni nič božanskega, je klasični topos poznoantičnih nasprotnikov čaščenja svetih podob.

7 Za krščanske apologete (in njihov odnos do umetnosti) gl. mdr. R. M. Grant, Greek Apologists of the Second Century, Philadelphia, 1988. Izbor besedil zgodnjih apologetov s spremno besedo in pomembnejšo bibliografijo je dostopen tudi v slovenskem prevodu Logos v obrambo resnice. Izbrani spisi zgodnjih apologetov (zbirka Cerkveni očetje), Celje, 1998.

8 "Ko bi goved in konji imeli roke in bi znali delati podobe, bi upodabljala goved goveje, konji konjske like bogov.« (Ksenofan, Fragmenti, 16, prev. A. Sovrè, v: Predsokratiki, Ljubljana, 1946, 68).

9 V prevodu A. Sovrèta, v: Predsokratiki, Ljubljana, 1946, 75.

10 Batrachomyomachia, 178-187 (dostopno v angleškem prevodu M. L. Westa, The Battle of Frogs and Mice v: Homeric Hymns, Homeric Apocrypha, Lives of Homer, Cambridge Mass./London, 2003, 262-293). 
Po njem so radi posegli krščanski apologeti in poznejši pisci, ki so našli še številne druge argumente za obsodbo čaščenja svetih podob. Enega ključnih in najpogosteje ponavljanih argumentov je ponudil Origen (ok. 185-254). Njegov razmislek je toliko bolj tehten, ker poskuša svojo kritiko utemeljiti v okviru filozofsko-teološke razprave. Sprašuje se, v kakšni meri, če sploh, je lahko slika resnična podoba Boga? Odgovor je zanj nedvoumen: nobena umetniška stvaritev se ne more približati resnični podobi Boga, saj Bog v svoji božanski naravi presega sleherno človeško zmožnost predstavljanja. ${ }^{11}$ Bog je absolutno transcendentno počelo vsega obstoječega, obstaja kot čista duhovna entiteta, brez podobe, ki bi si jo mogli zamisliti. Sleherni opis je lahko zgolj na ravni prispodobe ali simbola. Origenu se zdi še najustreznejša prispodoba s soncem. Kakor sonce iz sebe izžareva svetlobo, tako Bog emanira logos, ki je Božja beseda, po kateri je ustvarjeno vse, kar biva. Vendar nič ustvarjenega ne more posredovati njegove resnične podobe. Toliko manj nam jo lahko ponudi slika, ki je za Origena (enako kot za Platona, čigar dedič je v tem pogledu) zgolj posnetek ustvarjenih stvari in torej še bolj oddaljena od resničnosti. ${ }^{12}$

Vsi, ki gledajo sprijena dela slikarjev, kiparjev in podobarjev, živijo v temi in obtičijo v njej, kajti nočejo gledati kvišku ter se v duhu dvigniti od vidnih in čutnih stvari k Stvarniku vsega, ki je luč. (Origen, Proti Kelzu, VI, 66)

Vendar je k temu treba dodati, da Origenov odnos do likovne umetnosti ni povsem enoznačen. Cerkveni oče namreč dopušča možnost, da lahko določene podobe našemu umu nudijo neke vrste oporo pri premostitvi razlike med absolutno transcendenco Boga in človeško predstavo o Bogu. ${ }^{13}$

Origen se z vprašanjem likovne umetnosti zunaj omenjenega konteksta spoznavne teorije ne ukvarja posebej. Kljub temu je njegovo delo močno vplivalo na razvoj krščanske umetnosti, saj velja za enega od utemeljiteljev alegorične razlage Svetega pisma, s tem pa tudi prakse, ki v razlagah svetopisemskih vsebin uporablja prispodobe s področja vizualne komunikacije. ${ }^{14}$

Sveto pismo je delo božjega duha in nima le tistega pomena, ki je samoumeven, temveč še drugega, ki je večini bralcev skrit. Kajti vsebine Svetega pisma so

11 Gl. H. Crouzel, Origen, San Francisco, 1989.

12 Origen zaradi svoje spoznavne teorije podobno kakor Platonov Sokrat, ki je iz svoje idealne države izgnal večino umetnikov (gl. Platon, Država, $605 \mathrm{a}-\mathrm{b}$ ), zavrača likovno umetnost, saj ustvarja neadekvatne posnetke, ki odvračajo pozornost od bistvenega, to je božanskega, k nebistvenemu oziroma posvetnemu. Prim. Origen, Proti Kelzu, II, 31.

13 Origen ima v mislih alegorične oziroma simbolične podobe, čeprav tega ne izrazi povsem eksplicitno. Za Origenov odnos do likovne umetnosti gl. mdr. M. Barasch, Icon. Studies in the History of an Idea, New York/London, 1995, 136-138.

14 Origen ni prvi krščanski pisec, ki vzpostavlja alegorično razlago Svetega pisma. Tak pristop je uveljavljal že Klement Aleksandrijski (ok. 150-215), oba pa sta se zgledovala po Filonu Aleksandrijskem (ok. 25 pr. n. š. -50 n. š.), ki je razvil metodo alegorične interpretacije ob razlagi starozaveznih spisov. Za alegorično eksegezo Svetega pisma pri Origenu gl. klasično študijo H. de Lubac, Histoire et Esprit: L'Inteligence de l'Ecriture d'apres Origène, Pariz, 1950. 
vnanje oblike skrivnosti in podobe božanskih stvari. (Origen, O počelih, I, Predgovor, 8)

Velik del Origenovega opusa predstavlja razlaga Svetega pisma, ki je z vidika razvoja krščanske ikonografije najbolj plodovita dediščina njegovega pisanja. Z njo je sprožil razcvet alegorične biblijske eksegetike, hkrati pa je ustvaril pomembna ikonografska izhodišča za razvoj krščanske umetnosti. Prispodobno razlaganje je v polnem pomenu besede jezik podob, od metafore $\mathrm{v}$ pisani besedi do prispodobne govorice likovnih podob pa je le korak. Nagel razcvet krščanske likovne umetnosti v drugi polovici 3. stoletja to dovolj nazorno ilustrira. Podobe dobijo legitimnost in pravico do obstoja zaradi svoje sporočilne vrednosti. Če pogledamo spomenike zgodnjekrščanske umetnosti, se pokaže, da prevladujejo prizori alegoričnega in simbolnega značaja. Kristus dobri pastir je alegorični motiv, ki se vsebinsko navdihuje v Svetem pismu (Lk 15, 4-5, Jn 10, 2-16), oblikovno pa posega v antiko. Dejstvo, da so umetniki za tovrstno upodobitev Kristusa povzeli ikonografski tip Hermesa kriofora (Hermes, ki nosi ovco na ramenih), dodatno potrjuje moč alegorične interpretacije, ki se ne boji uporabiti lika poganskega božanstva in mu dati nove, krščanske vsebine. ${ }^{15}$ Med najpogostejšimi novozaveznimi motivi, ki se v tem času pojavljajo v slikarstvu katakomb in na sarkofagih, so tisti, ki slikajo Kristusove čudeže in so simbolična napoved odrešenja (Jezus obudi Lazarja, Ozdravljenje hromega, Ozdravljenje krvotočnice, Ozdravljenje moža, ki ga je obsedel hudi duh, Pomiritev viharja, Jezus nasiti množico ipd.). Enako velja za starozavezne prizore, kjer največkrat srečamo motiv rešitve iz stiske: Noe v barki, Mojzes izbije vodo iz skale, Jona, ki ga velika riba izpljune na obalo, Daniel v levnjaku, Trije mladeniči v ognjeni peči, Čista Suzana itd. Med simboličnimi upodobitvami prednjačijo simboli Kristusa, kot so križ, različne oblike Kristusovega monograma, vinska trta, jagnje, riba itd. ${ }^{16}$

Če smo v 3. stoletju priča hitremu vzponu krščanske umetnosti, ki pa je z likovnega vidika razmeroma skromna, pride s tolerančnim ediktom v začetku 4. stoletja do pomembne prelomnice. Naklonjenost cesarja Konstantina Velikega, ki naj bi tik pred smrtjo tudi sam sprejel krščanstvo, je bila za nov razcvet umetnosti ključnega pomena. Umetnost zdaj ni več skrita v katakombah in skromnih zasebnih oratorijih, temveč postane javna. Pri tem je opazna želja Cerkve, da upodabljajoče umetnosti pridobijo reprezentativen značaj. Četrto stoletje je čas, ko gradijo prve velike krščanske bazilike, za katere je potrebna tudi ustrezna notranja dekoracija. Prvič se pojavijo sijajni mozaiki, monumentalni cikli fresk, kiparsko okrašeni amboni, korne pregrade in kapiteli,

15 Hermes kriofor je že v antiki postal alegorični lik, ki pooseblja filantropijo ali ljubezen do bližnjega. Preskok v krščansko interpretacijo je bil zato toliko lažji. Za ikonografijo Kristusa v najzgodnejšem obdobju krščanske umetnosti gl. mdr. J. Kollwitz, Das Christusbild des. 3. Jahrhunderts, Münster, 1953.

16 Gl. G. B. Ladner, Handbuch der frühchristlichen Symbolik, Wiesbaden, 1996; A. Grabar, Christian Iconography: a Study of its Origins, Princeton, 1968. 
razkošno iluminirani rokopisi itd. To pomeni, da postanejo umetniška dela vidna široki javnosti in privzamejo povsem nove funkcije. Reprezentativnost upodobitev se kaže tako v umestitvi spomenikov v javni prostor in njihovi opaznosti, kakor v umetniški vrednosti, kvaliteti izdelave, umetnostni tehniki, dragocenosti materialov in drugih elementih.

Na ravni sporočilnosti in komunikacije z gledalcem pride do pomembnega preobrata tudi $\mathrm{v}$ smislu intenziviranja pripovednosti ( $\mathrm{v}$ 4. in 5. stoletju nastanejo prvi veliki pripovedni sklopi, ki govorijo o Kristusovem življenju in njegovih čudežih, vsebujejo pa tudi svetopisemske cikle $\mathrm{z}$ motivi iz Stare zaveze), v obravnavi umetniške snovi se uveljavlja naturalistični pristop, kar pomeni, da želijo umetniki čim bolj prepričljivo in nazorno upodobiti izbrane motive. $\mathrm{V}$ tem pogledu začne krščanska umetnost tekmovati s poznoantično in nima zadržkov pri prevzemanju likovnih prvin, ki sta jih razvili helenistična in rimska umetnost. Simbolični značaj ostaja ključna komponenta zgodnjekrščanske umetnosti, vendar tudi v simboličnih podobah umetniki uvajajo naturalistični pristop. $\mathrm{V}$ tem času se uveljavijo upodobitve Kristusa, ki presegajo raven alegoričnih figur, kot so Kristus dobri pastir, Kristus ribič ali Kristus učitelj. Upodobitve želijo biti čim bolj stvarne in prepričljive. Sočasno se okrepi tudi polemika o Kristusovi resnični zgodovinski podobi - tako krščanski kot poganski pisci resno razpravljajo o vprašanju Kristusovega videza in seveda o ustreznosti upodabljanja njegove osebe. ${ }^{17}$

Odnos Cerkve do likovne umetnosti v začetku 4. stoletja mogoče najbolje ilustrirajo zapisi cerkvenega zgodovinarja Evzebija iz Cezareje (ok. 263-339). Evzebij po eni strani odločno vztraja pri Origenovem prepričanju, da Boga ni mogoče upodobiti in da naj se ga torej sploh ne upodablja. V slovitem pismu Konstanci Avgusti, sestri cesarja Konstantina, ki je Evzebija prosila, naj ji pošlje kakšno podobo Kristusa, njeno prošnjo zavrne $z$ besedami, da prosi za nemogoče.

Kako bi mogel kdo narediti podobo Kristusa, ki je Logos, neupodobljiv v svoji božanski naravi? Ni ga mogoče upodobiti niti kot učlovečenega Božjega sina, saj njegov obraz sije kakor sonce in njegova oblačila so kakor luč. Kako bi mogel kdo z mrtvo barvo in risbo predstaviti njegov sijaj? Kako lahko kdo naslika podobo tako čudovite in nepojmljive oblike, razen če poskuša kakor neverni pogani predstaviti stvari, ki nimajo nikakršne podobnosti z ničemer? (Evzebij, Pismo Konstanci, PG 1545) ${ }^{18}$

17 O Kristusovem videzu najdemo prve zapise v apokrifih in gnostičnih spisih (Acta Andreae et Mathiae) ter v delih poganskih avtorjev, ki napadajo krščanstvo. V spisih cerkvenih piscev se najpogosteje pojavlja v odgovorih na njihove napade (npr. Origen, Proti Kelzu). Prve upodobitve Kristusa naj bi se pojavile v gnostičnih krogih, kot je razvidno iz pisanja Ireneja Lyonskega (Proti herezijam I, 25, 6). Najslikoviteje se razmišljanja o Kristusovi resnični podobi razcvetijo v krščanskih apokrifih. Gl. D. R. Cartlidge in J. K. Elliott, Art and the Christian Apocrypha, London, 2001.

18 Evzebijevo pismo Konstanci Avgusti je skupaj z latinskim prevodom objavljeno v grški patrologiji, vendar v angleškem prevodu dostopno tudi v: C. Mango, The Art of the Byzantine Empire, 312-1453 (Sources and Documents), New York, 1972, 16-17. 
Po drugi strani presenečeni ugotovimo, da Evzebij z vidnim navdušenjem opisuje bronasti spomenik, ki so ga meščani Cezareje postavili pred hišo, v kateri naj bi živela krvotočnica, ki jo je Kristus čudežno ozdravil. Spomenik naj bi predstavljal ženo, kako v drži priprošnjice kleči pred stoječim Kristusom, ki steguje roko proti njej. »Ta kip, za katerega pravijo, da ima Jezusove poteze, je bil še v mojem času na mestu in sem ga videl na lastne oči.«(Evzebij, Cerkvena zgodovina, VII, 18) Cezarejskemu škofu se bronasti kip Jezusa Kristusa tokrat ne zdi nič spornega. Prav tako se pohvalno izrazi o velikem reliefu Kristusa dobrega pastirja, s katerim je dal cesar Konstantin okrasiti javni vodnjak v Konstantinoplu (Evzebij, Konstantinovo življenje, III, 49). Kako je mogoče, da pisec Cerkvene zgodovine zavzema (na videz) tako nasprotujoča si stališča do svetih podob? Odgovor moramo iskati v razlikovanju tipov podob, ki korenini pri Origenu, katerega je Evzebij dobro poznal in občudoval. Evzebij (skupaj z Origenom) ne dvomi, da umetnost ne more ustvariti resnične podobe Kristusa. Lahko pa oblikuje alegorične in simbolične podobe, slike, ki jih Evzebij označuje z izrazom symbola. Možne, dovoljene in upravičene so upodobitve, ki poskušajo ujeti Kristusovo naravo skozi njegova dejanja, kakor so opisana v Svetem pismu. S tega vidika je podoba Kristusa, ki ozdravi krvotočnico, dopustna in primerna. Vendar ne smemo prezreti podrobnosti, ki razkriva razpoko v konsistentnosti Evzebijeve teorije o primernosti svetih podob. $\mathrm{V}$ teoretskem razmisleku Evzebij dopušča upodabljanje svetih oseb v natančno določenem kontekstu in funkciji, pri čemer likovno realizacijo določa njena vsebina: Kristus je lahko upodobljen bodisi na simboličen način, v alegoričnem kontekstu ali v svetopisemskih motivih, ki njegovo podobo opredeljujejo z vidika njegovih dejanj. Upodobitev naj bo torej vizualna predstava njegove duhovne odličnosti in usklajena z naukom, ki ga razširja. V praktičnem zaznavanju umetnosti pa opazimo odklon od takšne teorije. Evzebiju se namreč pri opisu cezarejskega spomenika hote ali nehote zapiše, kako za kip Kristusa v tej skupini pravijo, »da ima Jezusove poteze«, ne da bi se mu to zdelo kakor koli problematično. Kip, ki očitno poskuša biti čim bolj verodostojna upodobitev zgodovinskega Jezusa ali vsaj slovi kot tak, bi moral biti za Evzebija teoretika nesprejemljiv ali vsaj sporen. (Spomnimo se pisma Konstanci - Jezusa ni mogoče upodobiti, že sama želja po umetniški predstavitvi njegovega resničnega videza je nedopustna.) A ker se Evzebij tokrat vživi v vlogo gledalca, torej »uporabnika « umetnosti, ki spomenik gleda s povsem drugačne perspektive, se mu upodobitev Jezusa ne zdi sporna.

Cezarejski škof s tem nazorno razkriva razkorak med razpravljanjem o umetnosti in doživljanjem umetnosti ter posredno priznava, da je likovna umetnost celo v občutljivem primeru svetih podob avtonomen medij, ki ga ni mogoče podrediti izključno teološki in moralno-didaktični funkciji. Primer ponazarja spremembo, do katere je v razvoju krščanske umetnosti prišlo v zgodnjem 4. stoletju, in njene percepcije v krogih piscev, 
ki so oblikovali stališče Cerkve do upodabljajočih umetnosti. Pri vzpostavljanju bolj sproščenega odnosa do svetih podob igra pomembno vlogo tudi dejstvo, da se Evzebij kot visok cerkveni dostojanstvenik, svetovljan, Konstantinov varovanec in cerkveni zgodovinar jasno zaveda novega položaja krščanske cerkve, kiv spremenjenih okoliščinah nujno potrebuje svojo umetnost. Psihološka, reprezentativna in propagandna vloga likovne umetnosti je prevelika, da bi jo mlada cerkev smela podcenjevati.

Evzebijev odnos do umetnosti je povzela večina cerkvenih piscev 4. in 5. stoletja. Ti vprašanja likovne ustvarjalnosti praviloma ne problematizirajo tako izrazito kot njihovi predhodniki. Umetnost je zdaj v službi Cerkve, izdelovanje podob ni več vprašljivo, sporno je le njihovo čaščenje, ki pa v tem času še ne doseže skrb vzbujajočih razsežnosti. ${ }^{19}$ Težišče kompleksnega vprašanja razmerij med teoretskimi razmišljanji krščanskih piscev in likovno umetnostjo se prenese drugam: pisci ne prevprašujejo upravičenosti podob, temveč s svojim pisanjem vse bolj neposredno vplivajo na razvoj umetnosti. V prvi vrsti gre za oblikovanje krščanske ikonografije, ki se razvija pod okriljem alegorizirajoče biblijske eksegetike. Posebno vplivna je tipologija - eksegetski princip, ki išče vsebinske skladnosti med Staro in Novo zavezo (concordia veteris et novi testamenti). Razbiranje vsebinskih povezav temelji na alegoričnih razlagah starozaveznih motivov (t. i. tipov), ki prefigurirajo novozavezne dogodke (t. i. antitipe). Tipologija se je $\mathrm{v}$ prvih stoletjih krščanstva razvila v aleksandrijski katehetski šoli s Klementom Aleksandrijskim in Origenom na čelu, najpomembnejši patristični predstavnik pa je sv. Avguštin (354-430), ki je v boju proti manihejstvu prav s pomočjo tipologije dokazoval, da je Nova zaveza izpolnitev napovedi iz Stare zaveze in da med obema obstaja tesna povezanost v smislu dopolnitve božjega načrta od stvarjenja do odrešitve sveta. ${ }^{20} \mathrm{Z}$ vključitvijo likovne umetnosti v kontekst alegorizirajoče biblijske eksegetike se še veliko neposredneje kot prej vzpostavi razmerje med verbalnim in vizualnim, in sicer tako, da likovna umetnost služi kot ponazoritev in dodatna razlaga krščanskega nauka. Zaradi tega njena legitimnost niti v primeru upodabljanja svetih oseb ni več sporna in posledično se ta tema iz patristične literature 5. stoletja skoraj povsem umakne. ${ }^{21}$

$\mathrm{Z}$ vidika razumevanja vloge likovne umetnosti in njenega razmerja do pisane besede zaznamo v zgodnjem 6. stoletju pri krščanskih piscih nov vidik, ki ga v okviru

19 Sv. Avguštin sicer opozarja na neprimernost tovrstnega početja, ki je po njegovem mnenju znamenje praznoverja, vendar $\mathrm{v}$ tem ne vidi resnejše grožnje pravovernosti. Čaščenje podob se močneje razmahne šele v 6 . stoletju, ko se pojavijo številne čudodelne podobe, ki naj bi ne bile delo človeških rok (t. i. aheiropoietoi). Enega od vrhuncev doseže v Bizancu v 7. stoletju in s tem izzove ikonoklazem. Prim. J. Daniélu/H. I. Marrou, Zgodovina Cerkve. Od začetkov do Gregorja Velikega, Ljubljana, 1988; A. Cameron, The Language of Images: the Rise of Icons and Christian Representation, v: D. Wood (ur.), The Church and the Arts (Studies in Church History, 28) Oxford, 1992, 1-42.

20 Prim. J. Daniélu, Sacramentum futuri. Études sur les origines de la typologie biblique, Pariz, 1950.

$21 \mathrm{Z}$ vso silovitostjo se je $\mathrm{v}$ času ikonoklazma znova lotijo pisci razprav, povezanih s čaščenjem oziroma uničevanjem svetih podob $\mathrm{v} 8$. in 9. stoletju. 
svoje spoznavne teorije izpostavi Psevdo Dionizij Areopagit (pozno 5.-zgodnje 6. stoletje). ${ }^{22} \mathrm{~V}$ njegovem pojmovanju simbola, ki posredno posega tudi v razumevanje likovne umetnosti in vizualnega, ${ }^{23}$ je namreč poleg gnoseološke vrednosti v večji meri kot poprej izpostavljen čutno zaznavni oziroma estetski vidik simbolnih podob. Dotakne se vprašanja učinka, ki ga simbolna podoba izzove v gledalcu in s katerim je dodatno spodbujena želja po spoznavi. Zametke prepričanja, da simbolne podobe spodbujajo duha tudi zaradi ugodja, ki ga tak način spoznavanja vzbuja v človeku, najdemo že pri Klementu Aleksandrijskem, ki v znamenitem razmišljanju o vrednosti govorice simbolov pravi:

Vse, kar se kaže zavito $\mathrm{v}$ tančico, vzbuja občutek večje in bolj spoštovanja vredne resnice; kot, vzemimo, sadovi, ki se odslikavajo v vodi, kot oblike, ki dobe več privlačnosti in lepote, kadar jih le slutimo pod polprosojnim oblačilom. (Klement Aleksandrijski, Stromata, V, IX, 56)

Klement Aleksandrijski naravnost govori o privlačnosti in lepoti oblik kot o pomembnih kategorijah spoznavnega procesa, Psevdo Dionizij Areopagit, ki je njegova dela dobro poznal, pa še stopnjuje vlogo simbolnih podob: simboli imajo moč, da »vznemirijo« duha, da poskuša doumeti to, kar je skrito, da ga dobesedno vodijo na poti spoznave in da smo s pomočjo čutno zaznavnih podob vsak po svojih močeh povzdignjeni k zrenju božanskega. »Umi umevajo, kolikor jim je to pač dovoljeno; mi pa smo k božanskim motrenjem vodeni s čutnimi podobami.« (Psevdo Dionizij Areopagit, O cerkveni hierarhiji, I, 2; Kocijančič, 407)

Čeprav je Areopagitova estetika, ki je tesno povezana s teorijo spoznave in gnoseološko vlogo simbola, izrazito spekulativne narave, je čutno zaznavna komponenta jasno izražena prav na vizualni ravni. V platonski tradiciji namreč Areopagit vidu pripisuje najodličnejše mesto med vsemi čuti (Psevdo Dionizij Areopagit, O nebeški hierarhiji, XV, 3; Kocijančič, 391). Pri uporabi prispodob najpogosteje posega po likovnih podobah, in ko piše o simbolih, daje jasno vedeti, da gre za vizualne simbole:

22 Areopagit se $\mathrm{z}$ vprašanjem likovne umetnosti ne ukvarja pobližje in jo le mimogrede omenja $\mathrm{v}$ kontekstu različnih teoloških vprašanj, zlasti pri vprašanju spoznave Boga. Vprašanju lepega posveča več pozornosti, v njegovem pojmovanju lepote pa odmevajo misli Platona, Prokla in Plotina. Gl. U. R. Jeck, Philosophie der Kunst und Theorie des Schönen bei Ps-Dionysios Areopagita, v: Documenti e studi sulla tradizione filosofica medievale VII (1996), 1-38.

23 Areopagit je v tem pogledu dedič neoplatonistične filozofije, zlasti Plotina in Prokla. Skladno s plotinskim naukom o emanaciji božanske biti zagovarja stališče, da se lahko s pomočjo simbolov približamo Bogu, ker v njih kot v zrcalu odseva delček božjega bistva. Simbol je zanj čutno zaznavna podoba, ki v kompleksni dialektiki podobnosti in različnosti s tem, kar predstavlja, omejenemu človeškemu umu pomaga na poti k spoznavanju v svojem bistvu nespoznavnega Boga. Za pojmovanje simbola pri Areopagitu so ključnega pomena spisi $O$ nebeški hierarhiji, O cerkveni hierarhiji in $O$ božjih imenih. Vse našteto je dostopno v prevodu Gorazda Kocijančiča: Dionizij Areopagit, Zbrani spisi, Ljubljana, 2008. Gl. tudi Perl, E. D., Symbol, Sacrament and Hierarchy in St Dionysus the Areopagite, Greek Orthodox Theological Review, 30 (1994), 311-365. 
Da so pred tiste stvari, ki jih ni moč izraziti s podobo, smiselno postavljene podobe, in da so pred stvari, ki se jih ne da izraziti z liki, postavljeni liki, ni kriva - to lahko trdimo - le sorazmernost našega položaja, ki ne more biti neposredno pritegnjena v motrenja, dostopna le umu (potrebuje pač primerna in naravna vodenja kvišku, ki nam predočajo za nas dosegljiva izoblikovanja neizobličljivih in nadnaravnih uzrtij), temveč je tudi nadvse primerno, da mistični Izreki s pomočjo neizrekljivih in svetih ugank skrivajo sveto in skrivno resnico nadsvetnih umov ... (O cerkveni hierarhiji, II, 2; Kocijančič, 333)

Ko govori o približevanju Bogu skozi razbiranje simbolov, piše o »živopisnosti razodevajočih simbolov« ( $O$ nebeški hierarhiji, II, 1; Kocijančič 331) in o »lepih motrenjih snovnih podob « (O nebeški hierarhiji, II, 1; Kocijančič 331). ${ }^{24}$

Razodevanje Boga skozi simbolne podobe se pri Areopagitu pogosto povezuje s spoznavanjem in doživljanjem lepote. Lepote so sicer deležne vse stvari v stvarstvu, vendar je v podobah, ki vodijo našega duha $\mathrm{k}$ Bogu, deležnost na lepem večja in čistejša. Nenazadnje velja omeniti tudi dejstvo, da Areopagit v svojih razlagah uporabi prispodobo, ki izvira neposredno iz likovne umetnosti. V opisovanju duhovnega očiščenja in približevanja spoznavi Boga pravi, da smo v tem procesu kakor kipar, ki se je namenil izklesati kip iz marmorja, tako da odvzema material, ki zakriva (kiparjevo) vizijo kipa, ki jo marmorni blok skriva $\mathrm{v}$ sebi, in s takšnim odvzemanjem razkriva skrito lepoto. ${ }^{25}$ Metafora sicer ni izvirna, temveč je verjetno prevzeta od Plotina. ${ }^{26}$ Že samo dejstvo, da prispodobo povzema po Plotinu, je pomenljivo, saj ta neoplatonistični filozof visoko ceni umetnost, umetniško ustvarjalnost ter jezik podob in vizualnih simbolov. V Plotinovem opusu ne manjka prispodob s področja umetnosti, njegovo razumevanje simbolov pa je pravo poveličanje likovne govorice:

24 Prim. tudi »Možno je tudi iz najbolj nečastitljivih delov snovi ustvarjati oblike, ki niso neprimerne za nebeške resničnosti, saj je tudi sama snov prejela svoj obstoj od resnično Lepega - zato so v vsej njeni snovni razporejenosti nekakšni odmevi umevajoče čudovitosti in smo lahko po teh odjekih vodeni kvišku do nesnovnih praoblik, če le zmoremo - kakor je že rečeno - razumeti podobnosti na nepodoben način in če istih (resničnosti) ne opredeljujemo na isti način, ampak skladno in primerno glede na umevajoče ali čutno zaznavne lastnosti.«(O nebeški hierarhiji, II, 4; Kocijančič 340-341)

25 Kot opozarja Kocijančič, prispodoba, ki jo uporabi Areopagit, zaradi težko prevedljivega stavka ni povsem enoznačna. $V$ interpretaciji se naslanjamo na tradicionalno branje tega odlomka (C. Luibheid, P. Scazosso in drugi). Kocijančič v svojem prevodu podaja drugo različico: »Molimo, da bi se znašli v tem mraku, ki je nad lučjo, in da bi prek nevidenja in nespoznanja videli in spoznali Njega, ki je nad uzrtjem in spoznanjem - prav s tem da Ga ne bi videli ne spoznali, kajti to je resnično videnje in spoznanje -, ter da bi po odvzemu vsega bivajočega nadbitnostno izrekli hvalnico Nadbitnostnega, kakor tisti, ki se namenijo narediti sveto podobo táko, kakršna je bila sama po svoji naravi, odstranijo vse, kar je ovešeno okrog in ovira čisto motrenje skritega, ter razkrijejo zakrito lepoto sámo na sebi - in sicer zgolj z odvzemanjem." (Kocijančič, 166-167)

26 »Kako je mogoče videti, kakšna je lepota dobre duše? Zazri se vase in glej! Če vidiš, da še nisi lep, tedaj bodi kot slikar, ki hoče naslikati lepo sliko in pri tem nekaj zavrže in nekaj izpopolni, nekaj poravna in nekaj drugega izčisti, vse dokler se na sliki ne pokaže lep obraz; tako tudi ti odvrzi vse, kar je odvečno, popravi vse, kar je izkrivljeno, in se očisti, da bo vse, kar je mračnega, postalo svetlo, in ne ustavi se v klesanju svoje podobe, dokler ne zasije v božanskem sijaju kreposti ...« (Plotin, Eneade, I, 6, 9) 
Ne smemo misliti, da $\mathrm{v}$ svetu uma bogovi in blaženi najdejo napisane odgovore; vse, kar je tam izraženo, je čudovita podoba, takšna, kakor se zamišlja v duši modreca; vendar podobe niso naslikane, temveč bivajoče. Zdi se, da so to razumeli egipčanski modreci ... Kadar želijo prikazati neko modrost, ne uporabljajo česa, kar bi zamenjevalo glasove ali zaporedja zlogov, niti ne zlagajo besed in stavkov s pomočjo zaporedja črk, temveč ... narišejo podobe ter odredijo po eno sliko za vsako stvar ... Tako je bila vsaka slika po svoje razumevanje in modrost in substanca, vse to hkrati, ne pa diskurzivno umovanje in preudarjanje. (Plotin, Eneade, V, 5, 20-25)

Psevdo Dionizij Areopagit simbole razume na podoben način kot Plotin, z uporabo prispodob s področja umetniške ustvarjalnosti in poudarjanjem estetske vrednosti podob pa likovni umetnosti, ki jo sicer vpne v teorijo spoznavanja Boga, prizna odličnost, kakršno ji je pripisovala klasična antika in so jo zgodnjekrščanski pisci dolgo zavračali.

Areopagitova misel je imela daljnosežne posledice tako na Vzhodu kot na Zahodu, kar je razumljivo, saj so njegove besede uživale tako rekoč apostolsko verodostojnost. Anonimni avtor je namreč v srednjem veku veljal za tistega Dionizija, ki ga je v Atenah spreobrnil sam apostol Pavel. ${ }^{27} \mathrm{Na}$ Zahodu so ga v 9. stoletju hkrati poistovetili s sv. Dionizijem, pariškim škofom, ki naj bi bil ok. leta 250 mučen na Montmartru v Parizu, svojo odsekano glavo pa naj bi čudežno nesel še nekaj kilometrov, vse do današnje bazilike sv. Dionizija (St-Denis), kjer so ga pokopali in ustanovili znameniti samostan. ${ }^{28}$ Več kot pol tisočletja po nastanku areopagitskih spisov Suger (ok. 1081-1151), opat v samostanu sv. Dionizija, kjer so spise hranili, v hvalnici lepoti prenovljene opatijske cerkve $\mathrm{v}$ duhu Areopagitovega razumevanja čutno zaznavne vrednosti likovne umetnosti vzneseno zapiše:

Očaranega nad lepoto božje hiše me je živobarvni sijaj žlahtnih kamnov s sveto močjo odvrnil od zunanjih skrbi in obrnil mojo pozornost od materialnih stvari $\mathrm{k}$ duhovnim. Vzpodbujenemu $\mathrm{k}$ iskreni meditaciji se mi zazdi, da se vidim na skrajnem robu zemeljske oble - ne čisto v umazaniji zemlje in ne še v čistosti nebes - in po božji milosti se v duhu dvignem iz nižav v višave. (Panofsky, 62-64) ${ }^{29}$

Doživetje cerkvene notranjščine, napolnjene s svetlobo, ki lije skozi pisane vitraje in osvetljuje številne dragocene umetnine, ima moč, da povzdigne duha od lepih stvari

27 Pisec areopagitskih spisov je vse do 12. stoletja veljal za Dionizija Areopagita, o katerem je v Apostolskih delih (Apd 17, 22-34) rečeno, da je po pridigi sv. Pavla na atenskem Areopagu sprejel krščansko vero in se pridružil apostolu.

28 Dionizija Areopagita je v spisu Passio sanctissimi Dionysii (PL 106, 23-50) s pariškim škofom prvič poistovetil Hilduin, prvi prevajalec areopagitskih spisov v latinščino in opat samostana sv. Dionizija pri Parizu (St-Denis). S tem je ugled areopagitskih spisov v Franciji dodatno narasel.

29 Suger, De rebus in sua administratione gestis, navedeno po: E. Panofsky, Abbot Suger on the Abbey Church of St. Denis and its Art Treasures, Princeton, 1979, 62-64. 
$\mathrm{k}$ razmišljanju o stvarniku vse te lepote. Pomenljivo je, da se Suger, ki v nasprotju s sv. Bernardom zagovarja vlogo umetnosti v Cerkvi, ne sklicuje na avtoriteto papeža Gregorja Velikega, ampak na Dionizija Areopagita. Ne zato, ker se ne bi strinjal s papeževim stališčem, da je umetnost $\mathrm{v}$ službi vere, temveč zato, ker mu je $\mathrm{z}$ razvojne točke, ki sta jo v prvi polovici 12. stoletja dosegli evropska umetnost in kultura, veliko bližje Areopagitov razmislek o umetnosti, ki tudi s svojo estetsko vrednostjo povzdiguje duha, kakor stališče papeža, ki umetniška dela razume kot knjigo za nepismene. 


\section{Viri ${ }^{30}$}

(Psevdo) Dionizij Areopagit: Zbrani spisi, prev. G. Kocijančič, Ljubljana, 2008.

Evzebij iz Cezareje, Cerkvena zgodovina (Church History, prev. G. A. Williamson, London, 1989).

Evzebij iz Cezareje, Pismo Konstanci Avgusti (Epistula ad Constantiam Augustam), PG 1545.

Gregor Veliki, Pismo Serenu (Epistula ad Serenum), PL 77, 1128.

Heraklit Efeški, Fragmenti, prev. A. Sovrè, v: Predsokratiki, Ljubljana, 1946.

Klement Aleksandrijski, Stromata (Stromata, Buch I-VI., prev. O. Stählin, Leipzig, 1906).

Ksenofan Kolofonski, Fragmenti, prev. A. Sovrè, v: Predsokratiki, Ljubljana, 1946.

Origen, O počelih (On First Principles, prev. G. W. Butterworth, New York, 1966).

Origen, Proti Kelzu (Contra Celsum, prev. H. Chadwick, Cambridge, 1953).

Plotin, Eneade, prev. S. Blagojević, Beograd, 1984.

Tertulijan, O malikovanju (De idolatria), PL 1, 664D-665A.

\section{Literatura}

Barasch, M., Icon. Studies in the History of an Idea, New York/London, 1995.

Bevan, E., Holy Images: An Inquiry into Idolatry and Image-Worship in Ancient Paganism and in Christianity, London, 1940.

Cameron, A., The Language of Images: the Rise of Icons and Christian Representation, v: D. Wood (ur.), The Church and the Arts (Studies in Church History, 28), Oxford, 1992.

Cartlidge, D. R. in Elliott, J. K., Art and the Christian Apocrypha, London, 2001.

Chazelle, C. M., Pictures, Books and Illiterate: Pope Gregory I's Letters to Serenus of Marseilles, Word \& Image 6 (1990), 138-153.

Crouzel, H., Origen, San Francisco, 1989.

Daniélu, J., Sacramentum futuri. Études sur les origines de la typologie biblique, Pariz, 1950.

Daniélu, J. in Marrou, H. I., Zgodovina Cerkve. Od začetkov do Gregorja Velikega, Ljubljana, 1988.

Esler, Ph. F., The Early Christian World, London, 2004.

30 Navedeni viri so dostopni tudi na različnih spletnih straneh, za krščanske pisce npr. http://www. documentacatholicaomnia.eu/. 
Freedberg, D., The Power of Images: Studies in the History and Theory of Response, Chicago, 1989.

Grabar, A., Christian Iconography: a Study of its Origins, Princeton, 1968.

Grant, R. M., Greek Apologists of the Second Century, Philadelphia, 1988.

Ivanović, F., Symbol and Icon. Dionysius the Areopagite and the Iconoclastic Crisis, Eugene (Oregon), 2010.

Jeck, U. R., Philosophie der Kunst und Theorie des Schönen bei Ps-Dionysios Areopagita, v: Documenti e studi sulla tradizione filosofica medievale VII (1996).

Koch, H., Die altchristliche Bildfrage nach den literarischen Quellen, Göttingen, 1917.

Kollwitz, J., Das Christusbild des. 3. Jahrhunderts, Münster, 1953.

Ladner, G. B., Handbuch der frühchristlichen Symbolik, Wiesbaden, 1996.

Lane Fox, R., Pagans and Christians: In the Mediterranean World from the Second Century AD to the Conversion of Constantine, London, 2006.

Lubac, H. de, Histoire et Esprit: L'Inteligence de l'Ecriture d'apres Origène, Pariz, 1950.

Mango, C., The Art of the Byzantine Empire, 312-1453 (Sources and Documents), New York, 1972.

Panofsky, E., Abbot Suger on the Abbey Church of St. Denis and its Art Treasures, Princeton, 1979.

Perl, E. D., Theophany. The Neoplatonic Philosophy of Dionysius the Areopagite, New York, 2007.

Perl, E. D., Symbol, Sacrament and Hierarchy in St Dionysus the Areopagite, Greek Orthodox Theological Review 30 (1994), 311-365.

Rorem, P., Pseudo-Dionysius: a Commentary on the Texts and an Introduction to their Influence, Oxford, 1993.

Rorem, P., Biblical and Liturgical Symbols within the Pseudo-Dionysian Synthesis, Toronto, 1984.

Tatarkiewicz, W., History of Aestethics, II, Medieval Aesthetic, Haag/Varšava, 1970.

Valantasis R. (ed.), Religions of Late Antiquity in Practice, Princeton, 2000. 
Tine Germ

\section{Images as a Substitute for Words? The Notion of Visual Arts in Early Christian Writings}

Keywords: visual arts and early Christian writers, early Christian art, sacred images, early Christian iconography

This article deals with the relation between verbal and visual communication in the early Christian era and its influence on the perception of visual arts in the Middle Ages. Taking as its starting point the famous statement by Pope Gregory the Great that "what Scripture is to the educated, images are to the ignorant, who read in them what they cannot read in books," it traces the issue back to the early church fathers and Christian apologists, who rejected the practice of making images of God and other sacred images. Many of them categorically condemned the visual arts and branded artists as sinners that supported idolatry with works of art. The theological arguments against sacred images concentrate on the idea that it is completely impossible for any human being to imagine what God looks like, let alone make an image of Him. The only possible way to visualize and depict God is through symbolic and allegorical images. This idea, clearly formulated by Origen, marks the position of later church fathers as well, although even by the early fourth century the attitude towards sacred images and the visual arts had become less austere.

Eusebius of Caesarea followed Origen in his speculation on sacred images, yet he described the statue of Christ with the woman that had an issue of blood in his native Caesarea without questioning the artist's intention to render the image of Christ realistically and thus recreate the figure of the historical Jesus. Eusebius and the church fathers of the fifth century realized that the visual arts were very important media and could be applied to the purpose of the Church: images could be useful in spreading Christian teachings, illustrating interpretations of the Scriptures, and rendering them more comprehensible. Biblical exegesis thus found its counterpart in the allegorical and narrative motifs of early Christian art. Although the didactic value of early Christian art prevailed at least in the polemics on art, the aesthetic component seems to have been of less concern to the church fathers. Only at the beginning of the sixth century did the topic of aesthetic value begin to figure in Christian writings. Pseudo-Dionysius the Areopagite made some important observations on aesthetics in his description of the gnoseological function of symbolic images. He felt that visual symbols were the 
most appropriate instruments for learning about God Himself (who is beyond any definition or description that words can provide) because they could at least evoke some idea of His divine nature. However, what was new in the evaluation of symbols in their gnoseological function was the idea that the beauty of these images stimulates the mind to strive to attain knowledge of the divine order that rules the universe. Visual communication and the visual arts thus cease to be regarded as mere aids to the verbal message-a sort of picture-book for the ignorant "who read in them what they cannot read in books" - and begin to be considered autonomous media that by far transcend their didactic religious function. 